Academy of Sciences of the U.S.S.R., Leningrad, its subject being the "Earliest News of Watt's Steam Engine to Reach Russia". Another paper by Mr. Rhys Jenkins was entitled "The Note Book of Roger North and the Work of Sir. S. Morland in the Steam Engine". Roger North (1653-1734), a lawyer, was the brother of Francis North, Lord Guildford. In the British Museum is a note-book of his containing some leaves devoted to mechanical subjects. Some of the sketches were of what Mr. Jenkins referred to as "a two-cylinder, single-acting, high-pressure condensing engine with automatic valve gear". Was it an engine of Savery's, Newcomen's, Papin's or Morland's?
Morland in 1673 asked for a patent for "An engine capable of raising water to any height by the help of steam", and in 1682 showed an engine to the King. But in the seventeenth century many men were at work on the steam engine. Some were concerned with the philosophical aspect of the subject, others had in view applications in practice. It is quite possible, indeed likely, that there were other workers in the field of whom we have no knowledge. In historical research from time to time buried material comes to light, necessitating a revision of our conclusions, and it may yet be possible to discover the inventor of the engine as described by Roger North.

\title{
Watt Commemoration in Westminster Abbey
}

\section{Sermon by the Right Rev, P. F. D. De Labilliere, Bishop of KNaresborough}

What is a man profited, if he shall gain the whole world, and lose his own soul ?

S. Matt. xvi. 26.

$\mathrm{W}^{\mathrm{H}}$ E are celebrating to-day (January 19) the two hundredth anniversary of the birth of James Watt- "the improver of the steam engine" -whose gigantic statue yonder in the Chapel of St. Paul, with its inscription from the pen of Lord Brougham, testifies to the high honour in which he was held by the men of his generation.

The basic principles of the steam-engine, it would appear, were already known when Watt embarked upon his investigations-but its use had been confined almost entirely to providing a satisfactory method of draining water from the newlyopened coal-mines-"a giant with one idea" as Coleridge called it. It was James Watt who improved this steam pumping engine and made it available for driving other types of machinery, so that when he died in 1819, the "giant with one idea" was capable of being used for an almost infinite variety of purposes.

Thanks to Watt's inventive genius, man had successfully harnessed the power of steam to his triumphal chariot, and the stage was set for the inauguration of the Mechanical Age, which made Britain for nearly a century the workshop of the world.

Speaking of the erection of James Watt's monument in the Abbey, Dean Stanley writes :

"Well may the ancient pavement of the Church have cracked and yawned, as the enormous monster moved into its place, and disclosed to the eyes of the astonished workmen, rows upon rows of gilded coffins in the vaults beneath. ... . Well might the standard-bearer of Agincourt, and the worthies of the courts of Elizabeth and James, have started from their tombs in S. Paul's Chapel, if they could have seen this colossal champion of a new plebeian art enter their aristocratic restingplace. . . .

"Yet when we consider what this vast figure represents, what class of interests before unknown, what revolutions in the whole actual framework of society, equal to any that the Abbey walls have yet commemorated, there is surely a fitness even in its very incongruity."

We may truly, then, regard James Watt as one of the foremost pioneers of the Machine Age, and on this bicentenary of his birth concentrate our thoughts upon some of the ways in which mechanical invention has affected human life and thought.

Think for a moment of the extent to which the man of to-day lives his ordinary life under the domination of the machine. In our homes we rely upon electric light, vacuum cleaners, sewingmachines and consider them only half-furnished unless we have also a telephone, a wireless set and perhaps a gramophone as well. Small wonder that an eminent modern architect (de Courbousier) has defined a house as "a machine for living in". Our offices are equipped with typewriters, calculating. machines and cash-registers, if not with dictaphones.

We go out into our streets and count on being able to use electric trams or motor buses or 
underground tubes-and a growing number of daring folk are unhappy unless they can fly in the air.

There is no need to prolong the wondrous story. To tell it in detail would require volumes. The outstanding fact is obvious-the life of mankind to-day is controlled by mechanical devices as never before.

Now in some quarters this increasing mechanisation of life is viewed with frank dismay. Indeed, as Prof. Lecky pointed out ("Rationalism", 2, 349), "every step of the progress of machines was met by fierce opposition, directed at one time by the ablest statesmen, and long afterwards sustained by the lower classes". There are some still living who, apparently, could witness the absolute destruction of the 'machine' without shedding a tear.

Some thinkers even to-day refuse to admit that there is in it anything which is not wholly vilestill less that it contains any promise of good for the future. What Rupert Brooke called "the keen impassioned beauty of a great machine" is not for them. They are only able to see a hideous and well-nigh invincible giant-hard, glittering and inhuman-that dwarfs human personality, and both compels and symbolises a life of mad and unbroken monotony. Mr. Gandhi, for example, with his passionate concern for the spiritual welfare of India, would seem to desire a return to life on its old, simple terms--and he has, at times, spoken strange words in denunciation of railways and modern methods of manufacture.

That, however, is an attitude of intransigence which, I imagine, few of us would be proposed seriously to adopt. Some very deep instinct always asserts itself when we are tempted to condemn or belittle any large field of human activity. When we think calmly about it, surely it becomes plain that this vast advance of man in the control of Nature belongs to the line of his true evolution. We feel that God must have meant it-if God is indeed behind the whole evolutionary process, as we believe Him to be.

We see that what is really happening is that, by learning to harness the forces of Nature to his will, man is bringing nearer the day when human drudgery shall cease to be the lot of any man, and the spirit of man shall be released for higher ends.

We cannot but rejoice in the triumphant exercise of human brains which lies behind all this mechanical advance, and some of us at least believe that ultimately the perfect control of matter will be found to subserve spiritual ends. No-we are certainly not going to deplore or to denounce all this mechanical advance-but on the other hand, if we are wise, we are not going to be blind to its attendant dangers.
It is obvious that these two hundred years of scientific progress have brought us face to face with the question whether mechanical science is to be our master or our slave--whether she is to be used as the servant of man's spirit, or is to bring the spirit of man beneath the tyranny of the machine.

A recent writer has pointed out, for example, that the War was a clear instance of the triumph of man's inventive intellect over his powers of spiritual control, and that is a charge which it would be difficult indeed to refute. He points out that of all attempts to depict the soul of the war, and of the society that made it and endured it, that of the painter comes nearest to the truth. Speaking of an exhibition of War pictures, he affirms that the subject treated by the artists is not man, but his handiwork-not soldiers but the 'things' which soldiers use. Reduced to form, they appear as vast intricacies of girders or spansin white sheets of flame from roaring furnacesin colossal hammers--in the bulk of huge transports-in the rush of destroyers through rough seas-in the mouths of monster guns pointing skywards.

The next effort of the artist is to show what these 'things' produce. And here again men scarcely appear. All that is seen is wreckagethe splinters of trees, or the huge dents of shellholes on the earth's surface. The human agents, soldiers or workers, look like ants in an ants' colony, or figures from a child's storehouse of toys. They are minders or tenders of machines - creators in the first instance, but pre-eminently and finally creatures (victims) of what they have made.

No one can deny the truth of that grim description, and it shows how far eivilisation has gone astray. If life were what it ought to be, the figure of man would dominate the picture, and all that he has created or invented would appear as mere tools to promote the well-being and happiness of the race.

It is a bad sign when our inventive genius threatens to outstrip our powers of spiritual control. If man is to progress, and civilisation is to survive, spirit must reign supreme over machinery, and all the wondrous discoveries of the intellect must be brought into the service of the soul. No one can wisely suggest the turning back of the clock. We cannot, if we would, return to the stage-coach, the spinning-wheel and the tallow candle. We must win through by the aid of the machine we ourselves have created, not court defeat by its destruction; but if we are to do that, what is required is that our moral and spiritual 'lag' must be abolished.

As we look into our own hearts, or survey the world at large, there can be little doubt that our 
moral and spiritual powers have failed to keep pace with our new inventions. Ever since James Watt made his steam engine, and the era of scientific inventiveness got well under way, we have been absorbing ourselves in the creation, accumulation, elaboration of the means of living; but when we turn our thoughts from the means by which we live to the end for which we live, are we so sure that we are on a correspondingly higher moral level than our fathers? Are we not driven to confess that the splendid new powers with which science has furnished us are still too largely in the hands of the old selfishness, the old greed, the old ambition? And increasing material powers simply are not safe except with proportionately improving character.

A drunken man afoot is dangerous enough, but the danger is multiplied tenfold if the drunken man is allowed to drive a car. An angry man can work damage with his two bare fists, but his damage becomes dire calamity if you place him in a bombing aeroplane.

Enlarged powers spell enlarged peril if the soul does not grow. I suppose society could endure for a time without further new inventions. The question is, How long can it endure without a better spirit, a spirit capable of handling aright those enlarged powers which modern discovery has placed within our reach?

So the final challenge presents itself: How is our spiritual 'lag' to be compensated? Where are we to find that larger vision, that clearer insight, that new unselfishness which the modern situation so urgently demands?

If the question is urgent, the answer, for those of us who are Christians, is abundantly plain. "If any man be in Christ he is a new creation." Jesus Christ came to save the soul of the world, to produce a new type of man who shall be equal to the demands of each new age. He told us not to fear those who kill the body, but those who kill the soul; and no one can be blind to the mighty forces within us and around us which threaten the destruction of the soul.

The message of the Christian Gospel is that in the power of God, which is ours through Christ, we can overcome them all. Let us strive so to live that we may vindicate the supremacy of the soul, for what profit is there in anything that science can do without the soul. What does it profit individual, or nation, or civilisation to gain the whole world and lose the soul ?

\section{The Transformation of Energy*}

\section{By The Right Hon, Lord Rutherford, O.M., F.R.S.}

\section{Equivalence of Mass and Engrgy}

$\mathrm{O}^{\mathrm{N}}$ $\mathrm{NE}$ of the great advances of the last century was the recognition of the relation between heat and energy ; to the present century belongs the recognition of a fundamental relation between mass and energy. The existence of such a relation was first discussed by Hasenöhrl in a study of the properties of radiation; but the general formulation of the principle we owe to Einstein in 1905 as a consequence of the theory of relativity. On this principle, mass and energy are equivalent, and mass is to be regarded in a sense as a concentrated source of energy. The energy $E$, whether in potential or kinetic form, resident in a mass $m$, is given by $E=m c^{2}$, where $c$ is the velocity of light. If the energy of a system is increased, its mass is increased; if the energy decreases, the mass diminishes. For example, the mass of a rifle bullet in flight is slightly greater than at rest because of its additional kinetic energy. The mass

\footnotetext{
- From the Watt Lecture delivered before the Greenock Philosophical
} soclety on January 17. of a body increases when it is heated because its content of energy is increased.

In these cases, when we are dealing with matter in bulk, the changes of mass brought about by realisable changes of energy are exceedingly minute and quite beyond the possibilities of measurement. For this reason, it might be thought that the effect of the change in mass is on such a small scale that it may be disregarded. This is not so, for we shall see that the position is very different when we deal with flying particles like electrons and protons, which can be given speeds comparable with the velocity of light. At slow speeds, the mass of the electron is only $1 / 1,840$ of the mass of our lightest atom, hydrogen; but its mass increases rapidly with speed as we approach the velocity of light. Even for the fast electrons that are spontaneously liberated from the radioactive bodies, the mass of the electron is five or six times greater than for slow speeds. This change of mass is much greater when we examine the very energetic electrons which appear in the cosmic rays. 